\title{
PENGEMBANGAN MODEL PREDIKSI MADDEN JULIAN OSCILLATION (MJO) BERBASIS PADA HASIL ANALISIS DATA REAL TIME MULTIVARIATE MJO (RMM1 DAN RMM2)
}

(Prediction Model Development Madden Julian Oscillation (MJO) Based on The Results of Data Analysis Real Time Multivariate MJO (RMM1 and RMM2))

\section{Lisa Evana ${ }^{1}$, Sobri Effendy ${ }^{2}$ dan Eddy Hermawan ${ }^{3}$}

1. Alumnus Departemen Geofisika dan Meteorologi, FMIPA-IPB

2. Departemen Geofisika dan Meteorologi, FMIPA-IPB

3. Lembaga Antariksa dan Penerbangan Nasional, Bandung E-mail: Lisa_evana@yahoo.com

\begin{abstract}
Background of this research is the importance of study on the Madden Julian Oscillation, the dominant oscillation in the equator area. MJO cycle showed by cloud cluster growing in the Indian Ocean then moved to the east and form a cycle with a range of 40-50 days and the coverage area from 10N-10S. Method that used to predict RMM is Box-Jenkins based on ARIMA (Autoregressive Integrated Moving Average) statistical analysis. The data used RMM daily data period 1 Maret 1979-1 Maret 2009 (30 years). RMM1 and RMM2 is an index for monitoring MJO. This is based on two empirical orthogonal functions (EOFs) from the combined average zonal $850 \mathrm{hPa}$ wind, $200 \mathrm{hPa}$ zonal wind, and satellite-observed Outgoing Longwave Radiation (OLR) data. The results in form of the Power Spectral Density (PSD) graph Real Time Multivariate MJO (RMM) and long wave radiation (OLR = Outgoing Longwave Radiation) at the position $100^{\circ} \mathrm{BT}$, $120^{\circ} \mathrm{BT}$, and $140^{\circ} \mathrm{BT}$ that show the wave pattern (spectrum pattern) and clearly shows the oscillation periods. There is a close relation between RMM1 with OLR at the position $100^{\circ} \mathrm{BT}$ that characterized the PSD value about 45 day. Through Box-Jenkins method, the prediction model that close to time series data of RMM1 and RMM2 is ARIMA $(2,1,2)$, that mean the forecasts of RMM data for the future depending on one time previously and the error one time before. Prediction model for $Z_{t}=Z_{t}=1,681 Z_{t-1}-0,722 Z_{t-2}-0,02 a_{t-1}$ $0,05 a_{t-2 .}$. Prediction model for RMM2 is $Z_{t}=1,714 Z_{t-1}-0,764 Z_{t-2}-0,109 a_{t-1}-0,05 a_{t-2}$. The flood case in Jakarta January-February 1996 and 2002 are one of real evidence that made the MJO prediction important. MJO with active phase dominant cover almost the entire Indonesia west area at that moment.
\end{abstract}

Keywords: ARIMA, MJO, OLR, RMM1, RMM2

\section{PENDAHULUAN}

\section{Latar Belakang}

Curah hujan di Indonesia umumnya dipengaruhi oleh fenomena sirkulasi atmosfer baik skala global, regional, maupun lokal. Salah satu fenomena global yang mempengaruhi cuaca dan iklim Indonesia adalah Madden Julian Oscillation (MJO).

\begin{tabular}{ll}
\hline Penyerahan Naskah & $: 10$ September 2008 \\
Diterima untuk diterbitkan & $: 14$ Oktober 2008
\end{tabular}


Madden Julian Oscillation (MJO) merupakan model osilasi dominan dari variabilitas daerah tropik (Madden dan Julian, 1971). la dimanifestasikan dalam skala waktu antara 30-60 hari melalui anomali skala besar dari propagasi (penjalaran) proses konveksi ke arah timur. Fenomena MJO dapat menjelaskan variasi iklim di wilayah tropis.

Fenomena MJO terkait langsung dengan pembentukan kolam panas di Samudra Hindia bagian timur dan Samudra Pasifik bagian barat sehingga pergerakan MJO ke arah timur bersama angin baratan (westerly wind) sepanjang ekuator selalu diikuti dengan konveksi awan kumulus tebal. Awan konvektif ini menyebabkan hujan dengan intensitas tinggi sepanjang penjalarannya yang menempuh jarak 100 kilometer dalam sehari di Samudra Hindia dan 500 kilometer per hari ketika berada di Indonesia.

Badan Meteorologi Australia menggunakan indeks Real Time Multivariate MJO (RMM1 dan 2) untuk memonitoring MJO. Indeks ini melibatkan variabel angin pada ketinggian $200 \mathrm{mb}$ dan $850 \mathrm{mb}$, serta data OLR. Indeks ini dimaksudkan untuk menjelaskan secara efisien dan ekstrak variabilitas atmosfer yang langsung berhubungan dengan MJO.

Studi fenomena MJO hingga saat ini belum banyak dilakukan orang, terutama mengenai prediksi terjadinya MJO berbasis kepada hasil analisis data time series Real Time Multivariate MJO (RMM). Metode yang akan digunakan adalah metode BoxJenkins atau ARIMA (Autoregresive Integrated Moving Average).

Penelitian ini juga akan mengkaitkan fenomena MJO dengan curah hujan yang terjadi di beberapa kawasan barat Indonesia. Dipilihnya kawasan barat karena fenomena MJO paling dominan terjadi di Indonesia bagian barat.

Kejadian banjir pada tahun 1996, 2002, dan 2007 merupakan salah satu bukti nyata bahwa prediksi MJO penting dilakukan. Diduga, MJO dengan fase aktif saat itu dominan meliputi hampir seluruh kawasan barat Indonesia.

\section{Tujuan}

Tujuan penelitian meliputi:

1. Memodelkan data time series Real Time Multivariate MJO (RMM1 dan RMM2)

2. Menduga besarnya RMM yang terjadi di atas wilayah Indonesia untuk beberapa dekade mendatang (2-3 hari dari data).

3. Menganalisis keterkaitkan nilai RMM1 dan RMM2 dengan curah hujan yang terjadi di beberapa kawasan barat Indonesia (studi kasus: Jakarta, Lampung, Palembang, dan Kerinci) 


\section{METODOLOGI}

\section{Waktu dan Tempat Penelitian}

Penelitian ini dilaksanakan di Bidang Permodelan Iklim Lembaga Penerbangan dan Antariksa Nasional (LAPAN) Bandung selama bulan Maret-Juni 2009.

\section{Alat dan Data yang digunakan}

Alat yang digunakan dalam penelitian ini adalah komputer dengan software Microsoft Office 2007, SPSS 16, dan Matlab versi 7.1. Adapun data yang digunakan dalam penelitian ini adalah:

a. Data harian Real Time Multivariate MJO seri 1 dan 2 (RMM1 dan RMM2) periode 1 Maret 1979 - 1 Maret 2009 (30 tahun) yang diperoleh dari web-side http://www.bom.gov.au/bmrc/clfor/cfstaff/matw/maproom/RMM///

b. Data anomali pentad Outgoing Longwave Radiation (OLR) periode 3 Maret 1979 - 3 Maret 2009 yakni pada posisi $80^{\circ} \mathrm{BT}, 100^{\circ} \mathrm{BT}, 120^{\circ} \mathrm{BT}$ dan $140^{\circ} \mathrm{BT}$ yang diperolehdari web-side

http://www.cpc.noaa.gov/products/precip/CWlink/daily_mjo_index/proj_norm_order.as cii

c. Data curah hujan harian wilayah Jakarta, Palembang, Lampung, dan Kerinci tahun 2006-2008

d. Data curah hujan bulanan tahun 1995-2008 (Sta. Halim Perdanakusuma, Sta. Pondok Betung, Sta. Kemayoran, Sta. Cengkareng, Sta. Tanjung Priok)

\section{Metode Penelitian}

\section{Analisis Spektral}

Analisis spektral digunakan untuk mengestimasi fungsi densitas spektrum dari sebuah deret waktu. Analisis spektral merupakan modifikasi dari analisis Fourier sehingga analisis ini sesuai untuk deret waktu yang stokastik (Chatfield, 1984).

Secara definisi, jika $X t$ adalah proses stokastik dengan fungsi autokovarians $Y(k)$ dengan $k=\ldots,-2,-1,0,1,2, \ldots$, maka spektrum $f(\omega)$ adalah transformasi Fourier dari fungsi autokovarians, yang dalam ekspresi matematisnya adalah sebagai berikut:

$f(\omega)=\frac{1}{\pi} \sum_{k=-\infty}^{\infty} \gamma(k) \exp (-i \omega k)$

Analisis spektral dalam penelitian ini digunakan untuk menampilkan periode setiap gelombang yang tersembunyi dari sebuah data deret waktu. 


\section{Metode Box- Jenkins}

Metode prediksi Box-Jenkins meliputi 4 tahap yaitu identifikasi, pendugaan parameter model, pengujian model, dan peramalan.

\section{Identifikasi Model}

Sebelum melakukan pendeferensialan terlebih dahulu dilakukan identifikasi kestasioneran data yang digunakan. Apabila data yang digunakan tidak stasioner maka dilakukan pendeferensialan sehingga didapatkan time series yang stasioner.

Time series yang nonstasioner dapat diubah menjadi stasioner dengan cara mentransformasikan nilai-nilai time series tersebut. Jika time series tidak memiliki variasi musiman, maka transformasi ke bentuk yang stasioner seringkali digunakan transformasi beda pertama terhadap nilai-nilai time series asal. Jika pembedaan pertama belum menghasilkan time series yang stasioner, maka diperlukan pembedaan yang lebih komplek lagi.

Dalam identifikasi model, hal pertama yang harus dilakukan adalah:

a. Membuat plot data (time plot) yang bermanfaat untuk melihat secara kasat mata apakah data stasioner atau tidak.

b. Memeriksa plot dari fungsi autokorelasi (ACF) dan fungsi autokorelasi parsial (PACF) untuk melihat model dari data.

Untuk menentukan orde dari proses AR adalah dengan melihat PACF. Lain halnya dengan model MA untuk menentukan orde dari model ini digunakan ACF. Oleh karena itu untuk mengidentifikasi model deret waktu lebih baik digunakan kedua-duanya yaitu ACF dan PACF.

\section{Pendugaan Parameter Model}

Untuk membantu memilih model tentative (sementara), menggunakan hasil analisis autokorelasi dan autokorelasi parsial dengan panjang lag tertentu. Setelah model time series berhasil diidentifikasi, tahap berikutnya adalah menduga parameterparameter model tersebut. Salah satu cara yang mendasar untuk mendapatkan parameter-parameter tersebut adalah dengan cara mencoba-coba (trial and error) yaitu menguji beberapa nilai yang berbeda dan memilih satu nilai tersebut (atau sekumpulan nilai, apabila terdapat lebih dari satu parameter yang akan ditaksir) yang meminimumkan jumlah kuadrat nilai sisa/ nilai galat (sum of squared residuals) (Makridakis, 1988).

\section{Pengujian atau Validasi Model}

Setelah model ARIMA sementara ditentukan, tahap berikutnya adalah melakukan pemeriksaan diagnostik untuk menguji kelayakan model serta jika diperlukan menyarankan perbaikan. Salah satu cara yang dapat dilakukan adalah dengan 
menganalisis galat (residual). Dengan kata lain meneliti perbedaan (selisih) antara data observasi dan keluaran model. Nilai galat (kesalahan) yang tertinggal sesudah dilakukan pencocokan model ARIMA, diharapkan hanya merupakan gangguan random.

Kedua yaitu dengan mempelajari statistik sampling dari pemecahan optimum untuk melihat apakah model tersebut masih dapat disederhanakan. Asumsi-asumsi statistik yang mendasari model umum ARIMA, memberikan beberapa angka statistik yang harus dihitung setelah nilai-nilai koefisien optimum diukur. Misalnya saja, untuk setiap koefisien/ nilai parameter yang diperoleh akan terdapat galat sehingga bisa dihitung jumlah kuadrat nilai galat. Nilai koefisien yang terpilih adalah yang memiliki jumlah kuadrat nilai galat terkecil. Nilai galat dapat diperoleh dari:

$$
a_{t}=X_{t}-\hat{X}_{t} \quad \text { (Makridakis, 1988) }
$$

\section{Forecasting (Prakiraan)}

Langkah selanjutnya yaitu melakukan prakiraan (forecasting) jika model sudah cocok.

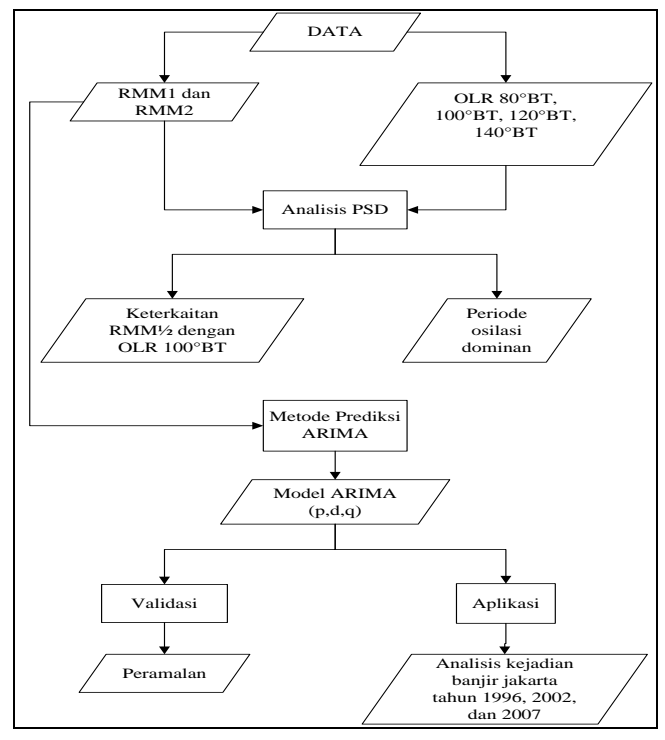

Gambar 1. Diagram alir penelitian 


\section{HASIL DAN PEMBAHASAN}

\section{Analisis Spektral Real Time Multivariate MJO (RMM1 dan RMM2) dengan Anomali Pentad Outgoing Longwave Radiation(OLR)}

Metode yang paling sering digunakan dalam menganalisis gelombang adalah analisis spektral. Analisis spektral berfungsi untuk memunculkan periode dari setiap osilasi yang terjadi. Setiap gelombang mempunyai periode osilasi tersendiri. Fenomena MJO terlihat jelas pada variasi OLR yang terukur dari sensor inframerah satelit. OLR atau radiasi gelombang panjang adalah jumlah energi yang dipancarkan bumi ke angkasa (Juniarti et al., 2002).

Berbagai penelitian telah menjelaskan tentang propagasi dan struktur vertikal MJO di atas Indonesia, namun data yang digunakan cenderung hanya menggunakan data Outgoing Longwave Radiation (OLR) dan radiosonde. Banyak cara yang dilakukan orang untuk memprediksi MJO. Satu diantaranya adalah dengan melihat perilaku data MJO indeks. Secara global fenomena MJO dapat terlihat berdasarkan metode Real Time Multivariate MJO (RMM1 dan RMM2) yang hingga kini digunakan pihak Badan Meteorologi Australia (BoM, Australia) dalam menganalisis fenomena MJO. RMM1 dan RMM2 adalah suatu indeks untuk memonitoring MJO yang didasarkan pada sepasang fungsi ortogonal empiris gabungan dari kecepatan angin pada $850 \mathrm{mb}$ dan $200 \mathrm{mb}$, serta data Outgoing Longwave Radiation (OLR) (Wheeler dan Hendon, 2004).

Hasil analisis spektral RMM1 dan RMM2 dengan OLR pada posisi $80^{\circ} \mathrm{BT}$, $100^{\circ} \mathrm{BT}, 120^{\circ} \mathrm{BT}$, dan $140^{\circ} \mathrm{BT}$ menunjukkan adanya osilasi dengan periode sekitar 45 harian (Gambar 1). Nilai kerapatan spektral yang paling besar yaitu pada OLR $100^{\circ} \mathrm{BT}$. Periode osilasi 45 harian dari PSD RMM dan OLR tersebut menunjukkan adanya fenomena Madden Julian Oscillation (MJO).

Secara umum RMM diaplikasikan untuk mengetahui perkembangan aktivitas MJO. Berdasarkan grafik PSD terlihat adanya keterkaitan antara Real Time Multivariate MJO dengan OLR pada posisi $100^{\circ} \mathrm{BT}$ karena diperoleh periode osilasi yang sama yaitu sekitar 40-50 hari. Hal ini sama dengan teori yang dikemukakan oleh Madden dan Julian bahwa fenomena MJO bersiklus 40-50 hari.

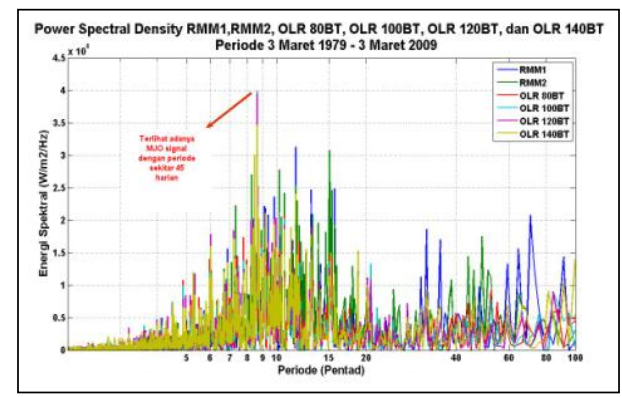

Gambar 2. Power Spectral Density (PSD) RMM1, RMM2, OLR $80^{\circ} \mathrm{BT}$, OLR $100^{\circ} \mathrm{BT}$, OLR $120^{\circ} \mathrm{BT}$, dan OLR $140^{\circ} \mathrm{BT}$ periode 3 Maret $1979-3$ Maret 2009 


\section{Model Prediksi Berbasis ARIMA \\ Uji Stasioneritas Data}

Data yang digunakan untuk membuat model prediksi ini yaitu data harian Real Time Multivariate MJO (RMM1 dan RMM2) periode 1 Maret 1979 - 1 Maret 2009. Pada penelitian ini analisis yang digunakan adalah ARIMA (Autoregressive Integrated Moving Average), karena melibatkan data deret waktu, sehingga diperoleh model yang menggambarkan data deret waktu tersebut.

Uji stasioneritas perlu dilakukan sebelum pembentukkan model karena peramalan pada data deret waktu mensyaratkan bahwa data harus bersifat stasioner. Jumlah pembedaan data deret waktu akan menjadi nilai orde d dalam model ARIMA yang digunakan. Suatu data dikatakan stasioner apabila nilai rata-rata dan variansnya konstan sepanjang waktu. Data yang tidak stasioner perlu dimodifikasi (dilakukan pembedaan) untuk menghasilkan data yang stasioner. Berikut ini adalah plot fungsi autorelasi (ACF), dan fungsi autokorelasi parsial (PACF).
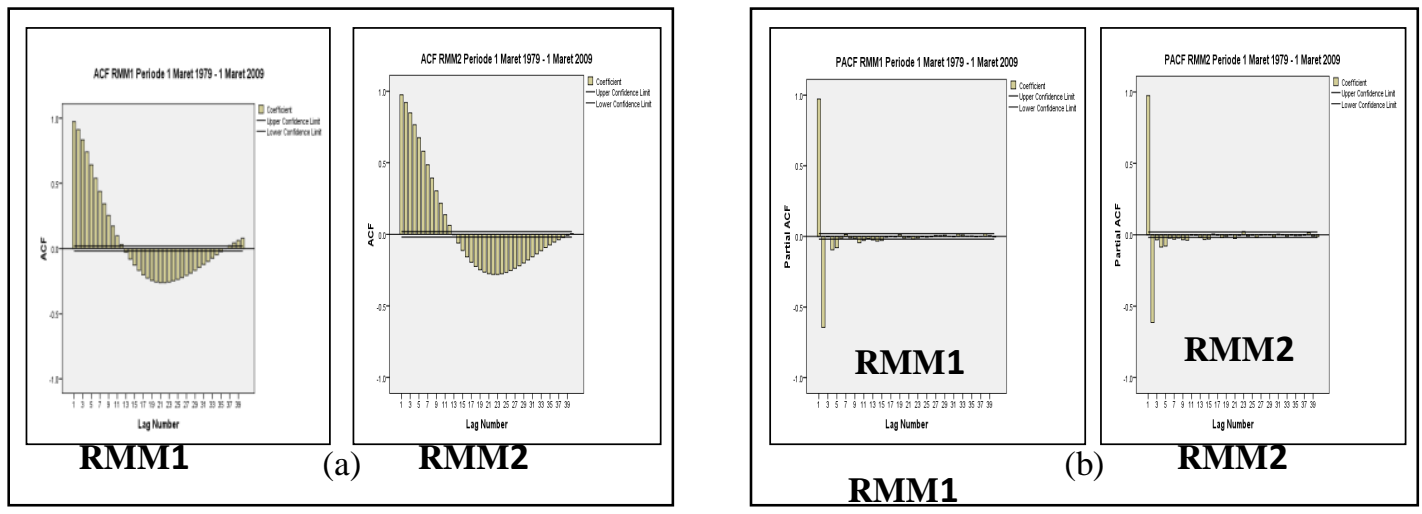

Gambar 2 Plot Fungsi Autokorelasi (ACF) (a) dan Fungsi Autokorelasi Parsial (PACF) (b) periode 1 Maret $1979-1$ Maret 2009

Kestasioneran dalam rataan dan ragam dari suatu proses deret waktu dapat dilihat secara visual dari plot data, fungsi autorelasi (ACF), dan fungsi autokorelasi parsial (PACF). Adanya pola alternating (naik turun secara teratur)(Gambar 3a). Setelah lag pertama nilai PACF menurun drastis dan seluruh PACF setelah lag 1 tidak signifikan secara statistik (Gambar 3b). Dua fakta tersebut menunjukkan bahwa data bersifat nonstasioner. Plot ACF dan PACF mengidentifikasikan adanya ketidakstasioneran dalam varian. Untuk menghilangkan pola musimannya sehingga data menjadi lebih stasioner maka dilakukan pembedaan pertama. Berikut ini adalah deskripsi statistik data asli, deskripsi data pembedaan pertama, plot ACF dan PACF pembedaan pertama. Dari plot data pembedaan pertama akan terlihat jelas apakah data telah stasioner atau belum. 
Tabel 1. Dekripsi statistik data Real Time Multivariate MJO (RMM1 dan RMM2) 30 tahun (1 Maret 1979-1 Maret 2009) dan data pembedaan 1

\begin{tabular}{lrrrrrrr}
\hline \multirow{2}{*}{ Variabel } & \multicolumn{1}{c}{ N } & \multicolumn{1}{c}{ Minimum } & \multicolumn{1}{c}{ Maximum } & \multicolumn{1}{c}{ Mean } & & \multicolumn{1}{c}{ Std. Dev } & Variance \\
\cline { 2 - 8 } & \multicolumn{1}{c}{ Statistic } & \multicolumn{1}{c}{ Statistic } & \multicolumn{1}{c}{ Statistic } & \multicolumn{1}{c}{ Statistic } & \multicolumn{1}{c}{ Std. Error } & \multicolumn{1}{c}{ Statistic } & \multicolumn{1}{c}{ Statistic } \\
\hline RMM1 & 10959 & -3.5079 & 3.9406 & .003757 & .0096820 & 1.0135657 & 1.027 \\
RMM2 & 10959 & -3.3625 & 3.8504 & -.008161 & .0096405 & 1.0092165 & 1.019 \\
dif1_RMM1 & 10958 & -1.0471 & .8069 & .000034 & .0022481 & .2353361 & .055 \\
dif1_RMM2 & 10958 & -.8783 & 1.0120 & .000032 & .0021556 & .2256462 & .051 \\
Valid N & 10958 & & & & & & \\
(listwise) & & & & & & & \\
\end{tabular}

Setelah dilakukan pembedaan pertama ternyata variasi data mengecil menjadi 0,055 untuk pembedaan data RMM1 dan 0,51 untuk data RMM2, begitu pula dengan nilai standar error data yang menurun setelah dilakukan pembedaan pertama (Tabel 1).

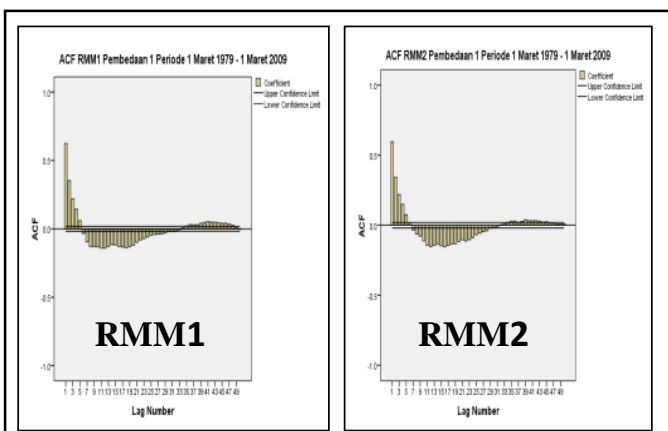

(a)

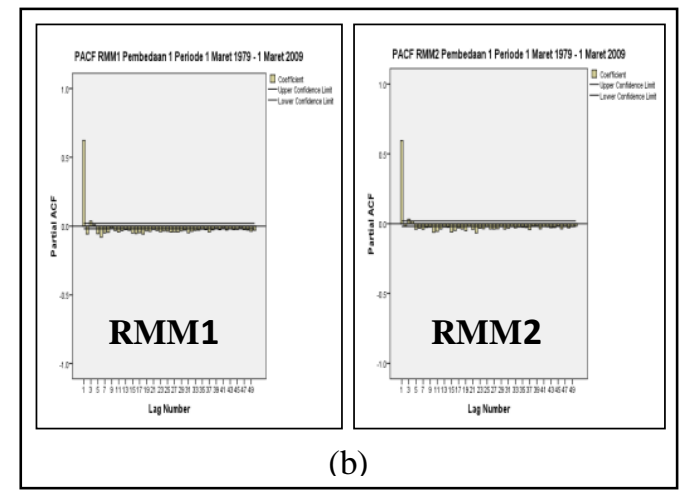

Gambar 4 Plot Fungsi Autokorelasi (ACF) pembedaan 1 (a) dan Fungsi Autokorelasi Parsial (PACF) pembedaan 1 (b) periode 1 Maret 1979 - 1 Maret 2009

Melalui plot ACF dan PACF data asli yang dilakukan pembedaan pertama, ditentukan model sementara data RMM1 dan RMM2 periode 1 Maret 1979-1 Maret 2009.

\section{Identifikasi dan Penaksiran Model}

Dari plot ACF (Gambar 4a) dan PACF (Gambar 4b) diperoleh informasi bahwa ACF RMM1 dan RMM2 signnifikan pada lag 1,2,3,4,5. Sedangkan PACF RMM1 dan RMM2 signifikan pada lag 1 dan 2. Dengan demikian model sementara dari plot data RMM1 dan RMM2 adalah campuran dari autoregresif, pembedaan pertama, dan moving average atau model ARIMA $(p, 1, q)$. Dengan nilai $p$ adalah 1 dan 2 sedangkan nilai $q$ dipilih 1,2 , 3, 4, dan 5. Selanjutnya dilakukan estimasi terhadap lag-lag yang ada untuk mendapatkan model terbaik. Setelah menetapkan identifikasi model sementara, selanjutnya parameter-parameter AR dan MA harus ditetapkan. 


\section{Uji Diagnostik}

Tahap selanjutnya yaitu uji diagnostik untuk membuktikan bahwa model tersebut cukup memadai. Pemeriksaan tersebut dilakukan dengan trial and error, melihat nilai Mean Absolute Deviation (MAD) dan Sum Square Error (SSE) untuk 10 model ARIMA yang mungkin. Mean Absolute Deviation (MAD) adalah rata-rata error (galat) hasil prediksi dengan nilai aktual. Sedangkan Sum Square Error (SSE) adalah jumlah kuadrat galat hasil prediksi dengan nilai aktual.

Tabel 2 Mean Absolute Deviation (MAD) dan Sum Square Error (SSE) untuk Model ARIMA data RMM1 dan RMM2 Periode 1 Maret 1979 - 1 Maret 2009

\begin{tabular}{|c|c|c|c|c|}
\hline \multirow{2}{*}{$\begin{array}{l}\text { Model ARIMA } \\
\text { RMM1 dan } \\
\text { RMM2 }\end{array}$} & \multicolumn{2}{|c|}{ MAD } & \multicolumn{2}{|c|}{ SSE } \\
\hline & RMM1 & RMM2 & RMM1 & RMM2 \\
\hline$(1,1,1)$ & 0,146241 & 0,143841 & 3854,43 & 3817,43 \\
\hline$(1,1,2)$ & 0,146216 & 0,143818 & 3853,32 & 3817,33 \\
\hline$(1,1,3)$ & 0,146192 & 0,144398 & 3852,80 & 3826,96 \\
\hline$(1,1,4)$ & 0,146861 & 0,143691 & 3859,88 & 3815,16 \\
\hline$(1,1,5)$ & 0,145766 & 0,143683 & 3846,83 & 3815,28 \\
\hline$(2,1,1)$ & 0,146220 & 0,783519 & 3853,23 & 8941,40 \\
\hline$(2,1,2)$ & 0,146200 & 0,143817 & 3852,73 & 3816,82 \\
\hline$(2,1,3)$ & 0,309278 & 0,143778 & 5799,44 & 3816,48 \\
\hline$(2,1,4)$ & 0,153393 & 0,141573 & 3941,58 & 3792,73 \\
\hline$(2,1,5)$ & 0,147356 & 0,140379 & 3869,22 & 3781,25 \\
\hline
\end{tabular}

Pemilihan model prediksi didasarkan atas besarnya MAD dan SSE serta kesederhanaan persamaan masing-masing model. Model yang memiliki nilai MAD dan SSE terkecil dibandingkan model lainnya adalah model ARIMA $(2,1,2)$, yang menggambarkan orde dari AR dan Ma adalah 2, dan derajat differencing sebesar 1(Tabel 2). Dengan melihat nilai MAD dan SSE sebagai ukuran model prediksi yang terbaik, maka model ARIMA $(2,1,2)$ layak dipilih sebagai model prediksi terbaik. Secara lengkap model ARIMA $(2,1,2)$ dapat dituliskan dalam bentuk persamaan (Cryer, 1986) sebagai berikut:

$Z_{t}=\left(1+\varnothing_{1}\right) Z_{t-1}+\left(-\varnothing_{1}+\varnothing_{2}\right) Z_{t-2}-\varnothing_{2} Z_{t-3}-\theta_{1} a_{t-1}-\theta_{2} a_{t-2}$

Berdasarkan Tabel 3 maka diperoleh model prediksi ARIMA $(2,1,2)$ untuk RMM1 yaitu

$$
Z_{t}=1,681 Z_{t-1}-0,722 Z_{t-2}+0,041 Z_{t-3}-0,02 a_{t-1}-0,05 a_{t-2} .
$$

Model prediksi ARIMA $(2,1,2)$ untuk RMM2 yaitu

$$
Z_{t}=1,714 Z_{t-1}-0,764 Z_{t-2}+0,05 Z_{t-3}-0,109 a_{t-1}-0,05 a_{t-2} .
$$


Model ARIMA $(2,1,2)$ mempunyai arti bahwa prakiraan data RMM1 dan RMM2 untuk waktu-waktu mendatang tergantung dari data RMM dua hari sebelumnya dan galat dua hari sebelumnya.

Tabel 3 Parameter Model ARIMA $(2,1,2)$

\begin{tabular}{|c|c|c|c|c|c|c|}
\hline & & & Estimate & SE & $t$ & Sig \\
\hline \multirow[t]{6}{*}{ RMM1-Model_1 } & \multicolumn{2}{|c|}{ Constant } & $3.883 E-5$ & .005 & .009 & .993 \\
\hline & \multirow[t]{2}{*}{ AR } & $\operatorname{Lag} 1$ (Ø1) & .681 & .388 & 1.753 & .080 \\
\hline & & Lag 2 (Ø2) & -.041 & .220 & -.185 & .854 \\
\hline & \multicolumn{2}{|c|}{ Difference } & 1 & & & \\
\hline & \multirow[t]{2}{*}{ MA } & $\operatorname{Lag} 1(\theta 1)$ & .020 & .388 & .051 & .960 \\
\hline & & Lag $2(\theta 2)$ & .050 & .040 & 1.244 & .213 \\
\hline & & & Estimate & SE & $t$ & Sig. \\
\hline \multirow[t]{6}{*}{ RMM2-Model_2 } & \multirow[t]{2}{*}{$\mathrm{AR}$} & $\operatorname{Lag} 1(\varnothing 1)$ & .714 & .342 & 2.090 & .037 \\
\hline & & Lag 2 (Ø2) & -.050 & .199 & -.249 & .804 \\
\hline & \multirow[t]{2}{*}{ MA } & $\operatorname{Lag} 1(\theta 1)$ & .109 & .342 & .319 & .750 \\
\hline & & Lag $2(\theta 2)$ & .050 & .018 & 2.771 & .006 \\
\hline & \multicolumn{2}{|c|}{ Constant } & $6.982 \mathrm{E}-5$ & .004 & .016 & .987 \\
\hline & \multicolumn{2}{|c|}{ Difference } & 1 & & & \\
\hline
\end{tabular}

\section{Peramalan}

Setelah melalui tahap identifikasi, pembedaan, dan pengujian maka diperoleh suatu model terbaik untuk memprediksi nilai RMM1 dan RMM2, yaitu model ARIMA $(2,1,2)$. Selanjutnya model ARIMA ini digunakan untuk memprakirakan nilai RMM1 dan RMM2 untuk hari berikutnya. Validasi dengan menggunakan model ARIMA $(2,1,2)$ untuk data RMM dari tanggal 2 Maret 2009 sampai 2 Juni 2009 (Gambar 4).

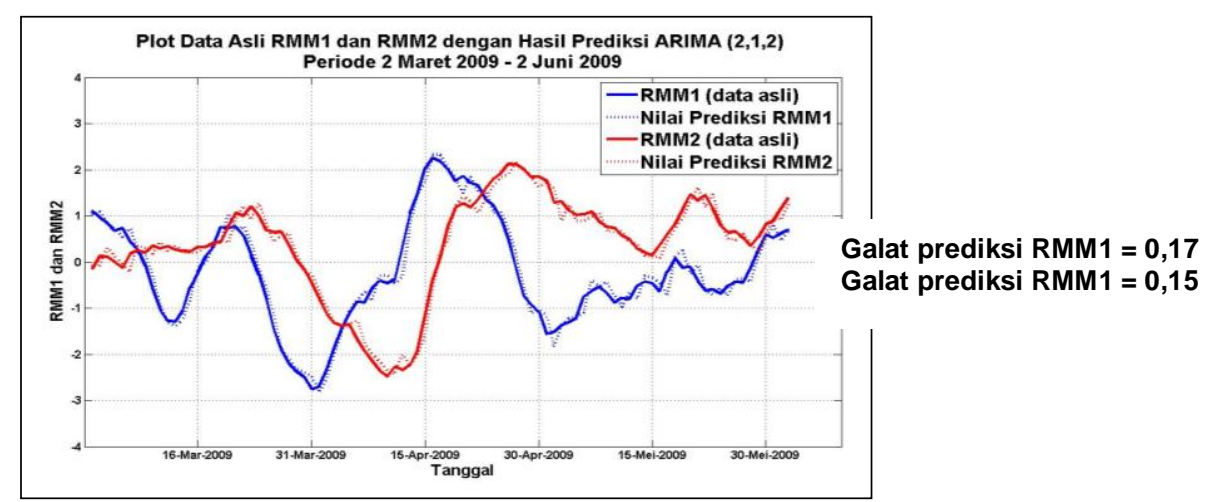

Gambar 5 Plot Data Asli RMM1 dan RMM2 dengan Hasil Prediksi ARIMA $(2,1,2)$ Periode 2 Maret 2009 - 2 Juni 2009 
Plot data prakiraan mendekati data asli dengan korelasi sebesar 0,984 atau 98,4 $\%$ untuk RMM1 dan 0,986 atau 98,6 \% untuk RMM2. Hasl prediksi dengan model ARIMA $(2,1,2)$ ini cukup baik karena menghasilkan nilai galat yang kecil. Prediksi RMM1 dan RMM2 ini sangat penting mengingat bahwa RMM merupakan suatu indeks untuk memonitoring MJO. MJO dibangkitkan oleh awan-awan Cumulunimbus, sehingga MJO juga berpengaruh terhadap curah hujan di Indonesia (Gambar 5).

\section{Analisis Hubungan MJO dengan Curah Hujan di Indonesia} (studi kasus: Kerinci, Palembang, Lampung, dan Jakarta.

Tipe curah hujan di wilayah Sumatera bagian selatan dan Jawa merupakan tipe curah hujan jenis Monsun. Musim hujan terjadi pada bulan Desember, Januari, dan Februari. Sedangkan musim kemarau terjadi pada bulan Juni, Juli, dan Agustus. Gambar 5 memperlihatkan distribusi curah hujan bulanan di wilayah Jakarta yang diwakili oleh Stasiun Tanjung Priok, Stasiun Halim Perdanakusuma, Stasiun Kemayoran, dan Stasiun Cengkareng dari tahun 1995 sampai tahun 2008.

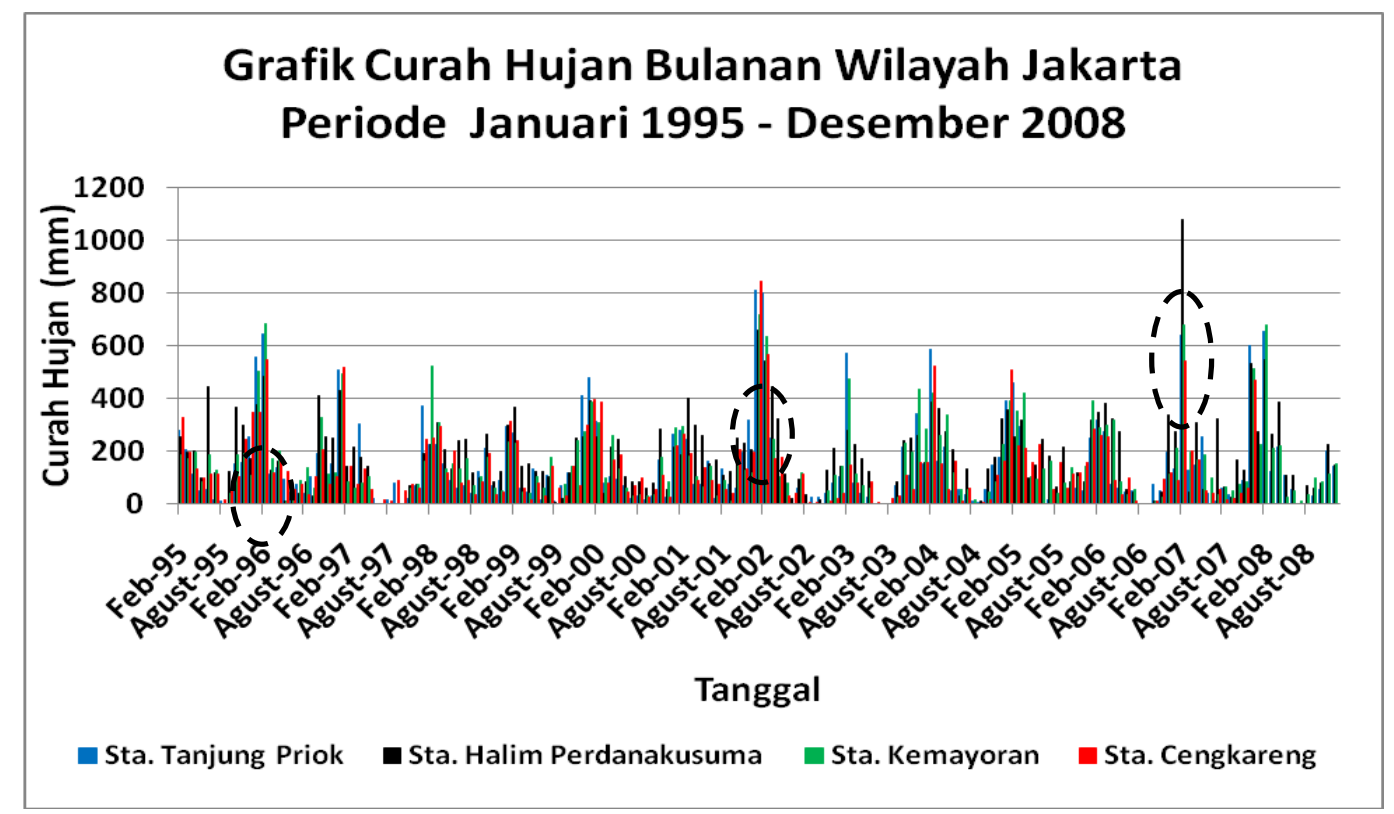

Gambar 6 Grafik curah hujan Jakarta periode Januari 1995 - Desember 2008

Curah hujan dengan intensitas tinggi di wilayah Jakarta terjadi pada bulan JanuariFebruari-Maret. Pada bulan Februari dan Maret hujan lebat terjadi hampir setiap hari. Sebagian berpendapat, ini adalah gejala alam biasa yang hampir terjadi setiap musim hujan. Bahkan ada yang menyatakan ini terkait erat dengan siklus lima tahunan yang menyebabkan Jakarta dan sekitarnya "tenggelam" akibat curah hujan dengan intensitas cukup tinggi. Hingga saat ini belum ada penjelasan ilmiah yang 
secara utuh, runut, terpadu, serta mudah dimengerti masyarakat awam mengapa terjadi hujan lebat dengan intensitas tinggi (Gambar 6).

Ada beberapa faktor lain yang menyebabkan intensitas curah hujan tinggi di daerah Jakarta. Secara geografis di utara Jakarta terbentang laut sebagai sumber uap air, sementara di bagian selatan Jakarta ada pegunungan di Bogor. Pengaruh lokal itulah yang kemudian memberikan andil besar semakin besarnya intensitas curah hujan di Jakarta pada Januari dan Februari.

Menurut Dr. Fadli Syamsudin, koodinator program Hydrometeorological Array for Intraseasonal Variation Monsoon Auto Monitoring (Harimau) Indonesia, salah satu faktor yang menyebabkan hujan dengan intensitas tinggi adalah kiriman uap air jenuh dari Samudera Hindia akibat Madden Julian Oscillation (MJO). Menurut Beliau MJO dalam fase aktif memiliki korelasi terjadinya intensitas curah hujan yang tinggi terhadap wilayah yang dilaluinya. Sejak peristiwa El-Nino pada tahun 1982-1983, variasi frekuensi rendah di wilayah tropis, baik itu waktu intra-annual (kurang dari setahun) dan inter-annual (lebih dari setahun), mendapatkan banyak perhatian dan hubungannya dengan MJO berkembang dengan cepat. Siklus MJO ditunjukan berupa gugus-gugus awan tumbuh di Samudera Hindia lalu bergerak ke arah timur (Matthews, 2000). Pergerakan super cloud cluster tentu saja berkaitan dengan pergerakan pusat tekanan rendah yang akan diikuti oleh perubahan pola angin (Seto, 2002).

Penelitian ini dilakukan dengan melihat bagaimana pengaruh MJO terhadap curah hujan di Indonesia, yaitu berdasarkan analisis data Real Time Multivariate MJO (RMM1 dan RMM2). Analisis ini difokuskan pada curah hujan bulan basah (DesemberJanuari-Februari-Maret) tahun 1996, 2002, dan 2007.

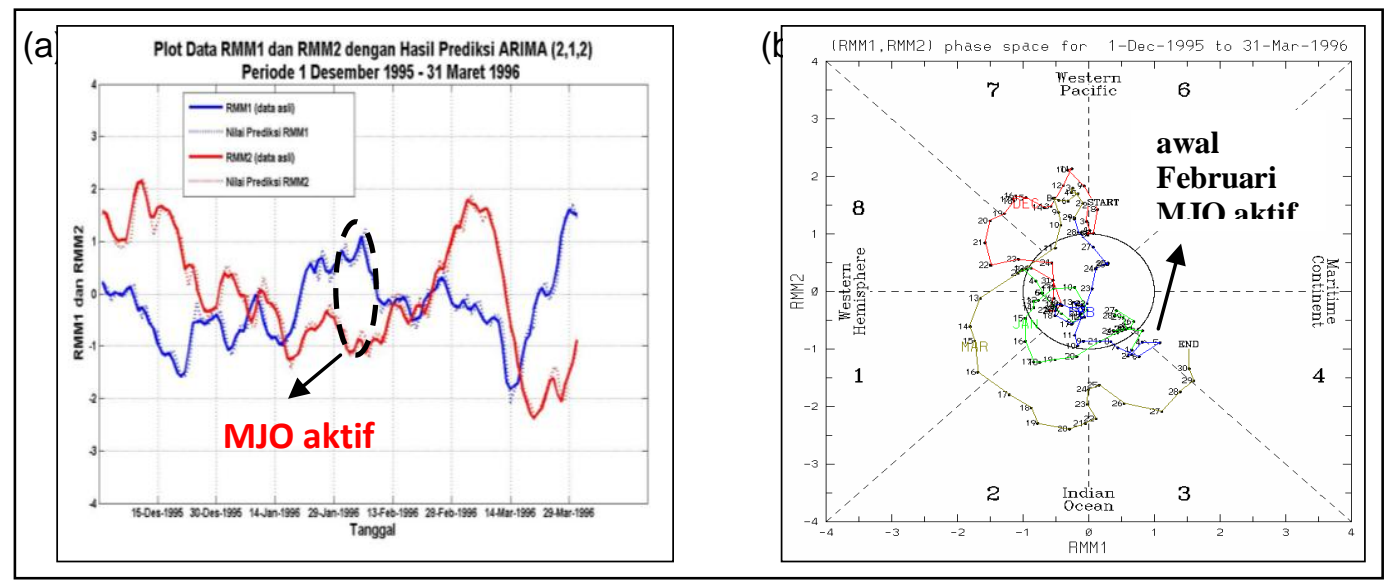

Gambar 7 Plot data RMM1/2 (a) dan diagram fase MJO (b) periode 1 Desember 1995 31 Maret 1996 (sumber: Bureau of Meteorology Research Centre, 1996) 


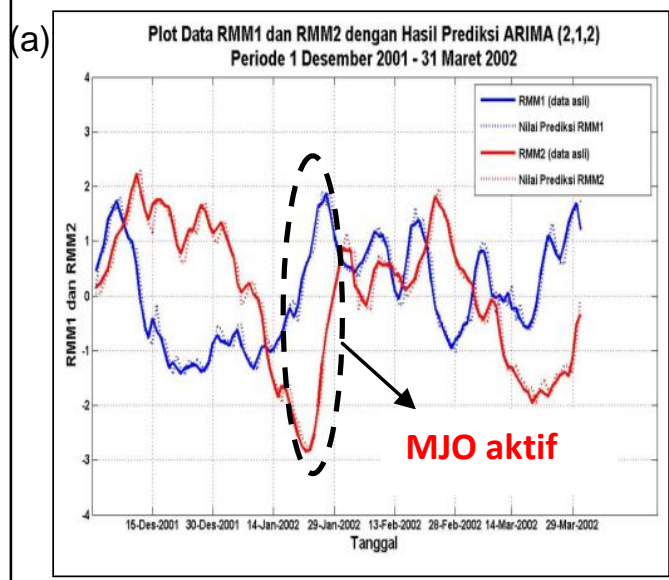

(b)

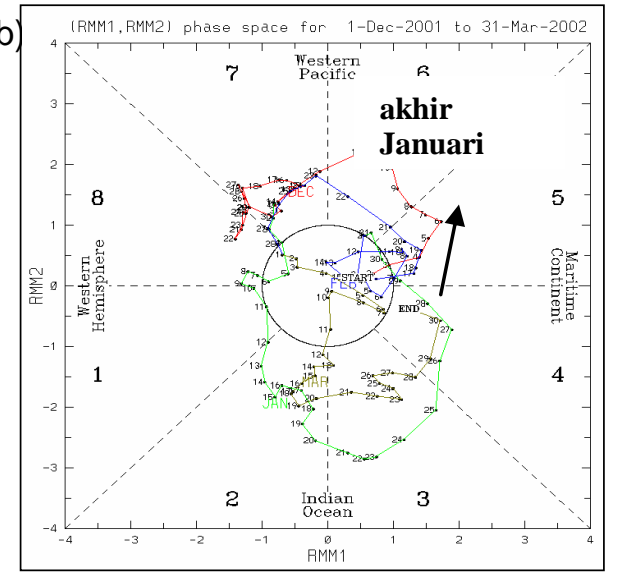

Gambar 8 Plot data RMM1/2 (a) dan diagram fase MJO (b) periode 1 Desember 2001 31 Maret 2002 (sumber: Bureau of Meteorology Research Centre, 2002)

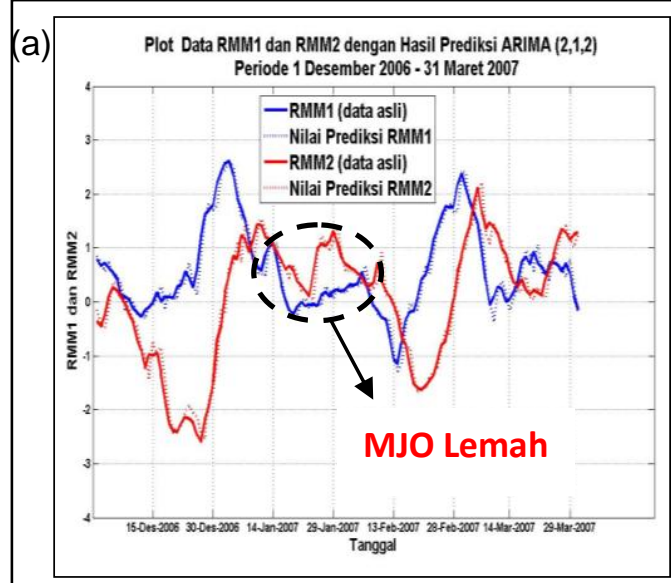

(b)

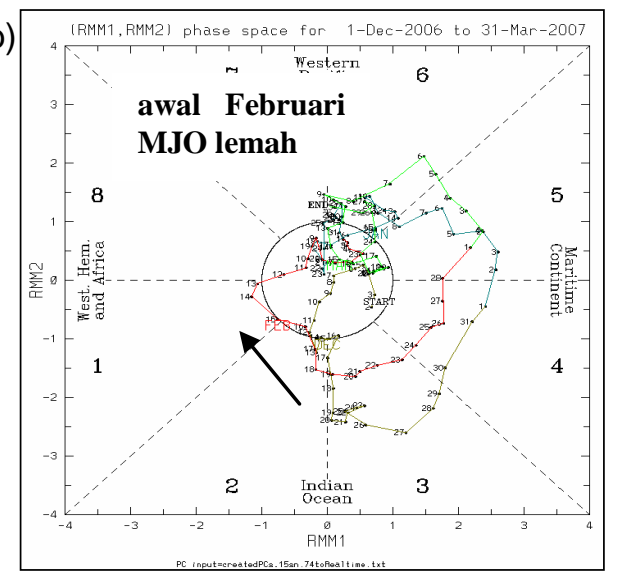

Gambar 9 Plot data RMM1/2 (a) dan diagram fase MJO (b) periode 1 Desember 2006 - 31 Maret 2007 (sumber: Bureau of Meteorology Research Centre, 2007)

Diagram pergerakan MJO pada Gambar 6, 7, dan 8 (b) memperlihatkan bagaimana fase MJO ketika curah hujan tinggi pada tahun 1996, 2002, dan 2007 yang menyebabkan banjir di Jakarta. MJO dikatakan dalam fase aktif jika $\sqrt{R_{M M 1^{2}+R M M 2^{2}}}>1$. Pada awal Februari 1996 tepatnya tanggal 3, 9, 10, 11 Februari MJO berada pada fase aktif, begitu pula pada akhir Januari 2002 (Gambar 7). MJO aktif tersebut berpengaruh pada meningkatnya curah hujan. Salah satu wilayah yang terkena dampaknya yaitu Jakarta.

Pada awal Februari 2007 terjadi banjir besar akibat sangat lebatnya curah hujan harian, terutama pada tanggal 1-5 Februari. Dugaan awal yatu bahwa ada pengaruh dari 
fenomena MJO pada saat itu, seperti yang terjadi pada tahun 1996 dan 2002. Namun dugaan awal itu salah karena berdasarkan data RMM dan melihat diagram fase pergerakan MJO, ternyata pada awal Februari 2007 MJO berada dalam fase lemah. MJO terlihat jelas dari aktivitas awan-awan $\mathrm{Cb}$ yang dapat dilihat berdasarkan data radiasi gelombang panjang (OLR). Untuk itu perlu dilihat bagaimana anomali OLR pada awal Februari 2007. Pada anomali OLR ternyata juga menunjukkan nilai yang positif pada awal Februari 2007 yang menunjukkan MJO tidak aktif. Analisis data RMM dan OLR semakin menguatkan argumen penulis bahwa curah hujan tinggi di Jakarta awal Februari 2007 bukanlah disebabkan oleh fenomena MJO. Hasil penelitian Peiming Wu et al. (2007), curah hujan sangat lebat yang menyebabkan banjir pada awal Februari 2007 disebabkan oleh pengaruh massa udara dingin yang bergerak dari Siberia ke kawasan ekuator melalui pesisir Jawa (cold surge), dan adanya pengaruh dari pergerakan Monsun yang melewati ekuator.

Analisis peluang curah hujan pada saat MJO difokuskan hanya di empat kawasan barat Indonesia, yaitu Jakarta, Lampung, Palembang, dan Kerinci pada tahun 2006, 2007, dan 2008. Peluang hujan lebat saat terjadinya MJO aktif adalah kecil (kurang dari 5\%) (Tabel 4). Pertumbuhan awan sampai mencapai tingkat matang dan menjadi hujan dibutuhkan inti kondensasi, uap air, energi dalam jumlah yang besar. Sehingga jika MJO aktif tetapi tidak menimbulkan curah hujan, hal itu dikarenakan awan-awan tersebut belum mencapai inti kondensasi sehingga terus bergerak dan bergabung dengan butir awan lain dan membentuk ukuran butir yang lebih besar lagi. 
Tabel 4 Peluang kejadian curah hujan $>50 \mathrm{~mm} /$ hari saat MJO aktif dan tidak aktif di wilayah Jakarta, Lampung, Palembang, dan Kerinci

\begin{tabular}{|c|c|c|c|}
\hline Stasiun & Tahun & $A(\%)$ & B (\%) \\
\hline \multirow{3}{*}{ Halim P. } & 2006 & 1.33 & 2.16 \\
\hline & 2007 & 0.95 & 3.23 \\
\hline & 2008 & 0.97 & 0.78 \\
\hline \multirow{3}{*}{ Kemayoran } & 2006 & 2.21 & 2.88 \\
\hline & 2007 & 3.33 & 3.23 \\
\hline & 2008 & 2.2 & 0.72 \\
\hline \multirow{3}{*}{ Tj. Priok } & 2006 & 1.77 & 0 \\
\hline & 2007 & 3.81 & 3.23 \\
\hline & 2008 & 2.64 & 1.45 \\
\hline \multirow{3}{*}{ PD. Betung } & 2006 & 0.99 & 1.8 \\
\hline & 2007 & 2.38 & 2.58 \\
\hline & 2008 & 3.08 & 0 \\
\hline \multirow{3}{*}{ Palembang } & 2006 & 1.77 & 2.16 \\
\hline & 2007 & 2.38 & 3.23 \\
\hline & 2008 & 3.08 & 2.17 \\
\hline \multirow{3}{*}{ Lampung } & 2006 & 2.46 & 0.99 \\
\hline & 2007 & 4.09 & 1.5 \\
\hline & 2008 & 2.2 & 0.72 \\
\hline \multirow{3}{*}{ Kerinci } & 2006 & 0.88 & 0.72 \\
\hline & 2007 & 1.03 & 0 \\
\hline & 2008 & 0.88 & 0 \\
\hline
\end{tabular}

Ket: $\mathrm{A}=$ Peluang $\mathrm{CH}>50 \mathrm{~mm} /$ hari saat $\mathrm{MJO}$ aktif $\mathrm{B}=$ Peluang $\mathrm{CH}>50 \mathrm{~mm} /$ hari saat MJO tidak aktif

\section{KESIMPULAN}

Melalui metode Box-Jenkins, model prediksi yang mendekati untuk data deret waktu RMM1 dan RMM2 adalah ARIMA $(2,1,2)$, yang artinya bahwa prakiraan data RMM1 dan RMM2 untuk waktu mendatang tergantung dari data dan galat dua hari sebelumnya.

Hasil validasi nilai RMM dengan nilai prediksi untuk periode 2 Maret 2009 - 2 Juni 2009 menunjukkan bahwa nilai prediksi dengan model ARIMA $(2,1,2)$ mendekati nilai RMM data asli, dengan rata-rata galat yang diperoleh yaitu 0,17 (RMM1) dan 0,15 (RMM2).

MJO fase aktif tidak selalu diikuti dengan hujan deras di Indonesia. Pada tahun 1996 dan 2002 MJO menjadi salah satu penyebab hujan deras (mencapai 200 mm/hari) yang menyebabkan banjir (studi kasus: Jakarta). Namun kejadian hujan deras yang menyebabkan banjir pada Februari 2007 terjadi ketika MJO dalam fase lemah, sehingga diduga ada fenomena lain yang menyebabkan hujan deras tersebut. 


\section{DAFTAR PUSTAKA}

Aldrian, Edvin. 2000. Pola hujan rata-rata bulanan wilayah Indonesia; tinjauan hasil kontur data penakar dengan resolusi ECHAM T-42. Jurnal Sains \& Teknologi Modifikasi Cuaca Vol. 1, No. 2, 2000:113-123.

Bureau of Meteorology Research Centre. An RMM values up to "real time". . http://www.bom.gov.au/bmrc/clfor/cfstaff/matw/maproom/RMM/// [10 Juni 2009]

Chatfield C. 1984. The Analysis of Time Series : An Introduction. London: Chapman and Hall.

Cryer JD. 1986. Time Series Analysis. USA: PWS Publishers.

Hermawan, Eddy. 2002. Perbandingan antara Radar Atmosfer Khatulistiwa dengan Middle and Upper Atmosphere Radar dalam pemantauan angin zonal dan angin meridional. Warta LAPAN 4, 1:8-16.

Juniarti et al. 2002. Korelasi antara Outgoing Longwave Radiation (OLR) dan Total Precipitable Water (TPW) di wilayah Indonesia periode 1996 - 1999. Kontribusi Fisika Indonesia 13:3.

Lestari D. Cold Surge dan MJO Pemicu Banjir Bandang. Antara News 14 Februari 2009.

Madden RA, Julian P. 1972. Description of global -Svale circulation cells in tropics with a 40-50 day period. J Atmos Sci 29:1109-1123.

Madden RA, Julian P. 1994. Observations of the 40-50 day tropical oscillation. Month Weather Rev 122:814-837.

Makridakis. 1988. Metode dan Aplikasi Peramalan. Jilid Satu Ed ke-2. Untung SA dan Abdul B, penerjemah. Jakarta: Erlangga. Terjemahan dari: Forecasting, 2nd Edition.

Matthews AJ. 2000. Propagation mechanisms for the Madden-Julian Oscillation. Quart $J$ Roy Meteor Soc 126: 2637-2652.

[NOAA] National Oceanic and Atmospheric Administration. Monitoring and data Outgoing Longwave Radiation. http://www.cpc.noaa.gov/products/precip/CWlink/daily_mjo_index/proj_norm_order.as cii [17 Juni 2009]

Seto TH. 2002. Pengamatan Osilasi Madden Julian dengan radar atmosfer equator (EAR) di Bukittinggi Sumatera Barat. Sains \& Teknologi Modifikasi Cuaca 3:121-124.

Wheeler MC, Hendon HH. 2004. An all-season real-time multivariate MJO index: development of an index for monitoring and prediction. Month Weather Rev 132:19171932.

Wu, Peiming et al. 2007. The impact of trans-equatorial Monsoon flow on the formation of repeated torrential rains over Java Island. SOLA 3:93-96. 